logos_i_ethos_2019_1_(49), s. 123-142

DOI: http://dx.doi.org/10.15633/lie.3438

Tomasz Czakon

https://orcid.org/0000-0001-5697-3651

Uniwersytet Śląski w Katowicach

\title{
Wzory osobowe polityka w kodeksach etycznych radnych
}

Filozofowie (etycy) od dawna interesują się relacjami między ety$\mathrm{kąa}^{1}$ i polityką. Jednocześnie, niezależnie od rozstrzygnięć badaczy, polityka i politycy byli i są oceniani także z punktu widzenia norm moralnych. Dzieje się tak również dzisiaj. Obecne jest także przekonanie, że polityka jest niemoralna (nieetyczna). W konsekwencji pojawia

Tomasz Czakon - zajmuje się filozofią społeczną oraz etyką społeczną. Opublikował: Wolność i dobro. Problem wolności w katolickiej filozofii społecznej w Polsce po 1989 roku, Katowice 2005; Wspótczesna filozofia społeczna w Polsce (współredaktor), Katowice 2009; Filozofia wobec globalizacji (redaktor), Katowice 2009; Między paternalizmem a restrykcyjnościa. Prawa pracownicze w kodeksach etycznych firm, Torun 2013; Kodeksy jako narzędzie budowy instytucji totalnej, Gliwice 2015. się żądanie „moralnej polityki” (z jej licznymi pułapkami) ${ }^{2}$, a jednym ze sposobów likwidacji (przynajmniej ograniczenia) nieetycznych zachowań w polityce miałyby być kodeksy etyczne polityków, szczególnie obecność w nich wzorów osobowych polityka (polityków). Takie kodeksy są konstruowane i przyjmowane przez

1 W artykule, mając świadomość odmienności pojęć „etyka” i „moralność”, bardzo często używam ich zamienne, przy czym „etyka” używana jest tutaj najczęściej jako synonim etyki normatywnej.

2 Zob. m.in.: J. A. Majcherek, Demokracja, przygodność, relatywizm, Warszawa 2007, passim; Janusz A. Majcherek, Hipertrofia moralności jako zagrożenie dla demokracji, w: Wartości w świecie polityki, red. nauk. J. Miluska, Poznań 2012, passim. 
polityków. Przeanalizowałem 58 kodeksów etycznych radnych ${ }^{3}$, poszukując odpowiedzi na pytanie, czy i w jaki sposób próbują przeciwdziałać nieetycznej polityce, jaki występuje w nich wzór dobrego polityka, radnego. Wzór ten zestawiam z kilkoma, sformułowanymi przez etyków, wzorcami polityka, radnego. Kodeksy etyczne radnych są przedmiotem zainteresowania z kilku powodów. Kodeksy te są liczne, dlatego można pokusić się o ich porównanie, odkrycie rodzajów pojmowania różnych elementów konstruujących etos polityki/polityków, czego nie można osiągnąć, analizując analogiczne, pojedyncze dokumenty polityków krajowych. Dzięki temu można próbować zweryfikować (sfalsyfikować) dość częste, jak sądzę, przekonanie opinii publicznej o wyższości etosu radnego, zajmującego się sprawami bliskimi wyborcom, nad etosem polityków ogólnokrajowych, zajmujących się (według tych opinii) sprawami oderwanymi od problemów większości ludzi. W artykule ocena trafności przekonania o wyższości etosu radnego zostanie tylko zasygnalizowana. Pełna ocena wymagałaby przedstawienia bardziej rozbudowanego materiału, czego nie sposób zrobić w artykule. Wreszcie, radni są najbardziej liczną grupą polityków, chociaż wielu z nich kwestionuje to, że są politykami. Jednak są politykami, ponieważ podejmują decyzje dotyczące ważnych spraw swoich wspólnot. Uczestniczą w sprawowaniu władzy. Duża część należy do partii politycznych o zasięgu ogólnokrajowym. Duża część należy do regionalnych i lokalnych ugrupowań politycznych (protopartii). W ten sposób radni uczestniczą nie tylko w podejmowaniu decyzji dotyczących ich jednostek samorządu terytorialnego, lecz również uczestniczą w kształtowaniu polityki regionalnej i ogólnokrajowej. W wielu wypadkach istnieją również przejścia od polityki lokalnej/regionalnej (bycia radnym) do polityki krajowej (bycia posłem, senatorem, ministrem, członkiem aparatu rządowego) i z powrotem. To nie są izolowane światy. W ten sposób badanie wyobrażeń etycznych radnych o etycznej polityce ma również bardziej ogólne znaczenie.

3 Kodeksy pochodzą z wszystkich regionów Polski i zostały przyjęte przez radnych różnych szczebli samorządu terytorialnego: gmin, miast, miast na prawach powiatów. 
Istnieją różne poglądy filozofów w sprawie relacji między etyką i polityką ${ }^{4}$. Przyjmuje się, że dawniej, w czasach przednowożytnych, dominowało przekonanie o jedności etyki i polityki, a nawet niezbędności podporządkowania polityki moralności. Natomiast poczynając od Machiavellego, głosi się odrębność, czy też autonomię obu sfer, ponieważ polityka i moralność kierują się różnymi kryteriami. Moralność kieruje się zasadami dobra, a polityka - skuteczności. W okresie tym (po Machiavellim) upowszechnia się również pogląd, że polityka jest w swojej istocie niemoralna, amoralna (aetyczna), a wiązanie polityki $\mathrm{z}$ moralnością rodzi poważne niebezpieczeństwa, łącznie z narzucaniem obywatelom jednej koncepcji moralnej ${ }^{5}$. $\mathrm{Z}$ drugiej strony wielu, a być może większość ludzi z żalem stwierdza, że faktycznie uprawiana polityka nie jest moralna ${ }^{6}$ (o czym mają świadczyć codzienne fakty zachowań polityków) i oczekuje, domaga się powrotu moralnej polityki. Z pewnością takie jest dominujące nastawienie, choć także współcześnie aktywni są zwolennicy poglądu o jedności polityki i moralności ${ }^{7}$. Pojawiające się co jakiś czas badania opinii publicznej potwierdzają negatywne opinie o polityce i politykach. Podejmowane są próby przeciwdziałania istniejącym w polityce (wśród polityków) zachowaniom nieetycznym (deficytom etycznym). $Z$ jednej strony są to propozycje etyków przedstawiających swoje oczekiwania wobec polityków, a z drugiej - samych polityków formułujących zasady swojego postępowania.

4 Zob. E. Modzelewski, Etyka a polityka, Warszawa 2006.

5 Przykładem może być wypowiedź M. Szyszkowskiej. Zob. M. Szyszkowska, Wprowadzenie, w: Polityka a moralność, pod red. M. Szyszkowskiej, T. Kozłowskiego, Warszawa 2001, s. 9-10.

6 Stefan Konstańczak przypomina pogląd, że moralność nie jest obojętna dla polityki, moralność stanowi spoiwo, dzięki któremu istnieje consens dotyczący podstawowych wartości. Zob. S. Konstańczak, Odkryć sens życia w swej pracy, Słupsk 2000, s. 127-132.

7 Pogląd taki głosi M. A. Krąpiec, O ludzka politykę, Katowice 1993, passim; M. A. Krąpiec, Ludzka wolność i jej granice, Warszawa 1997, passim, a także S. Kowalczyk, Człowiek a społeczność. Zarys filozofii społecznej, Lublin 1994, passim. 


\section{Kodeksy etyczne polityków}

Największe zainteresowanie budzą zasady regulujące postępowanie parlamentarzystów. Jednym $\mathrm{z}$ bardziej znanych i uznanych są zasady przyjęte w Wielkiej Brytanii przez tzw. Komisję Nolana. W październiku 1994 roku została powołana Komisja ds. Norm w Życiu Publicznym. Inicjatorem tego przedsięwzięcia był John Major, ówczesny premier Wielkiej Brytanii. Komisja zaproponowała kilka zasad, które powinny zapewnić etyczne reguły postępowania w sferze styku biznesu i polityki. Nieprzestrzeganie tych zasad nie niesie za sobą żadnych przewidzianych prawem sankcji. Normy opracowane w trakcie prac Komisji zawierały siedem zasad ${ }^{8}$ : bezstronności, niezawisłości, obiektywizmu, odpowiedzialności, jawności, uczciwości, przywództwa. Kodyfikacje zawodowe wielu zawodów w licznych krajach europejskich oparte są na tych zasadach. Dotyczy to także Polski.

W Polsce kodeks etyki poselskiej został przyjęty przez sejm uchwałą

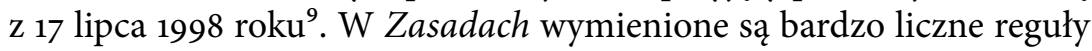
konstruujące wzór osobowy polityka. Według tego dokumentu poseł powinien postępować w sposób odpowiadający godności posła, a w szczególności zgodnie z zasadami: bezinteresowności, jawności, rzetelności, dbałości o dobre imię sejmu, odpowiedzialności.

W przypadku kodeksów etycznych radnych pojawiło się także kilka propozycji określających, jaka powinna być ich treść.

W wypowiedziach dotyczących pożądanych treści takiego kodeksu zwraca się przede wszystkim uwagę na cnoty polityków ${ }^{10}$. Zdaniem autorów Etycznych aspektów działalności samorządu terytorialnego zasady

8 Etyczne aspekty działalności samorządu terytorialnego. Poradnik dla samorządów, pod red. J. Filek, Kraków 2004, s. 210.

9 W sprawie kodeksu etycznego posłów zob. Uchwała Sejmu Rzeczpospolitej Polskiej z dnia 17 lipca 1998 Zasady etyki poselskiej, http://www.sejm.gov.pl/prawo/zep.htm; oraz jego omówienie: Z. Zell, Kodeks poselski, „Wspólnota. Pismo Samorządu Terytorialnego” 1998 nr 33, s. 6.

10 W sprawie kodeksów etycznych radnych: Etyczne aspekty działalności samorządu terytorialnego. Poradnik dla samorząów, dz. cyt., wersja cyfrowa, s. 155 oraz załącznik 13, gdzie przedstawiono propozycję wzorcowego kodeksu etycznego radnych. 
postępowania proponowane $\mathrm{w}$ tym opracowaniu $\mathrm{w}$ postaci wzorcowego kodeksu etycznego radnych są zbieżne z propozycjami dotyczącymi pracowników samorządowych. Wzorcowy kodeks nakazuje radnym postępować zgodnie z zasadami: praworządności, bezstronności i bezinteresowności, obiektywizmu, uczciwości i rzetelności, odpowiedzialności, jawności, dbałości o interes publiczny, godnego zachowania przy wykonywaniu funkcji radnego, uprzejmości i życzliwości w kontaktach z obywatelami. Twierdzi się tam także, że w treści kodeksów etycznych radnych powinny znaleźć się zasady dbałości o interes publiczny, unikania konfliktu interesów, unikania stronniczości w podejmowaniu decyzji lub podejmowania jej w sytuacji nacisku, przestrzegania dyscypliny finansowej i budżetowej. Wzorcowy kodeks nie przewiduje żadnych sankcji, a jego upowszechnienie zleca przewodniczącemu organów stanowiących jednostek samorządu terytorialnego.

Nieco inna propozycja wzoru osobowego radnego obecna jest w Honorowym kodeksie radnego ${ }^{11}$. Kodeks ten zwraca uwagę na praworządność, nieobecność konfliktu interesów, działanie w imieniu całej społeczności, szczególnie w imieniu tych, którzy na radnego głosowali, zdolność do podejmowania samodzielnych decyzji nawet w obliczu presji swojego ugrupowania politycznego. Radny nie powinien robić czegoś, czego nie potrafiłby wytłumaczyć swoim wyborcom. Każda z tych zasad posiada mniej lub bardziej rozbudowane wersje. Ciekawym wątkiem tego kodeksu jest uwzględnienie relacji między radnymi a urzędnikami. Dokument wymaga, aby radni respektowali zadania, obowiązki i odpowiedzialność urzędników i nie domagali się (nie akceptowali) preferencyjnego traktowania.

Chociaż kodeksy etyczne polityków (radnych) są przejawem instytucjonalizacji etyki, to zasygnalizowane propozycje kodeksów nie przewidują nakazu organizowania szkoleń etycznych, powołania rzecznika do spraw etyki ani komisji etycznych. Nie nakazują przeprowadzenia publicznych dyskusji przed jego przyjęciem.

11 Honorowy kodeks radnego, w: Standardy etyczne radnych i pracowników samorządowych, red. M. Korkuć, P. Stańczyk, Kraków 2000, s. 75-77. 
W dyskusjach dotyczących etyki polityki (polityków) rzadkie są wypowiedzi zwracające uwagę na instytucjonalny kontekst uprawiania polityki i w konsekwencji także instytucjonalny charakter etyki polityki. Jedną $\mathrm{z}$ ciekawszych propozycji, zwracających uwagę na ten pomijany wątek, przedstawił Ryszard Legutko ${ }^{12}$.

Legutko wychodzi od pytania: „czy etyka osobowa jest jednocześnie etyką publiczną? Wyrażając to prościej: czy jeżeli ktoś jest człowiekiem przyzwoitym i spełnia wymogi etyki, to wystarcza, aby w etyczny sposób wypełniał funkcje publiczne?"13. Stwierdza, że odpowiedzi na to pytanie było i jest wiele, jedni sądzą, że wystarcza, a inni to kwestionują. Zwolennicy takiego podejścia uważają, że etyka osobowa jest etyką publiczną: „wystarczy być człowiekiem dobrze uformowanym moralnie, aby jednocześnie działać zgodnie z etyką publiczną?" ${ }^{\prime 4}$. Zwolennicy drugiego stanowiska, pisze, twierdzą, że etyka osobowa nie ma nic wspólnego z etyką publiczną. Istotę tego poglądu przedstawia następująco: „Innymi słowy, jeżeli instytucje są dobrze skonstruowane, jeśli mamy czytelne zasady oraz dobrą egzekucję tych zasad, to nie ma znaczenia, kto w tych instytucjach uczestniczy. Mogą to być ludzie moralnie wątpliwi, ale logika instytucji jest taka, że zmusza ich do działania zgodnie $\mathrm{z}$ owymi zasadami. Jeżeli postępują inaczej, to - automatycznie - instytucje tych ludzi eliminują"15.

Legutko wyraża przekonanie, że obie odpowiedzi są jednostronne i naiwne. Łatwiej, pisze, skrytykować niż przedstawić własną propozycję, własne rozwiązanie. Rozwiązanie jest trudne, ponieważ trudno powiedzieć, jakim zasadom ma być posłuszna osoba pełniąca funkcje przedstawicielskie. Wyróżnia trzy poziomy odpowiedzialności: a) wobec instytucji, do której została wybrana; b) wobec wyborców; c) wobec własnego sumienia. „Każda odpowiedź będzie tutaj niesatysfakcjonująca i może spotkać się z zasadną krytyką. [...]. Jeżeli poseł mówi, że ma

12 Zob. R. Legutko, Etyka instytucji publicznych, w: Standardy etyczne radnych i pracowników samorządowych, dz. cyt., s. 11-17.

13 R. Legutko, Etyka instytucji publicznych, dz. cyt., s. 11.

14 R. Legutko, Etyka instytucji publicznych, dz. cyt., s. 11.

15 R. Legutko, Etyka instytucji publicznych, dz. cyt., s. 12. 
służyć państwu, to natychmiast spotkać się może z zarzutem, iż dokonuje aktu uzurpacji; wszak został wybrany po to, by realizował cząstkowe cele pewnej grupy. Również nie możemy argumentować, że powinien on działać zgodnie z własnym sumieniem, ponieważ działalność polityczna nie jest jednostkowa, lecz zbiorowa; zarówno cele, jak i odpowiedzialność wyznaczone są zbiorowymi decyzjami. Kto chce zachować zgodność między czynami a własnym sumieniem, to nie powinien działać politycznie. To samo dotyczy argumentu, że działanie deputowanego powinno być zgodne z tymi celami, jakie wyznacza ugrupowanie, które go delegowało. W takim przypadku człowiek taki staje się marionetką i przestaje być podmiotem moralnym" ${ }^{16}$. Na postawione pytanie, pisze, nie ma dobrej odpowiedzi, choć intuicja etyczna sugeruje, że trudno aprobować działania polityka, który kieruje się tylko jednym czynnikiem, np. kierował się tylko racjami wyborców albo własnym sumieniem, lekceważąc racje państwa.

Powyższe propozycje Legutki są bardzo ciekawe przy próbie uporządkowania i oceny propozycji wzorów osobowych radnego obecnych w ich kodeksach etycznych.

Przeanalizowałem 58 kodeksów etycznych radnych: gmin wiejskich, miejskich, miejsko-wiejskich, miast na prawach powiatów, powiatów. Przedmiotem badania było wiele problemów, tutaj zasygnalizuję tylko wybrane, które tworzą wzór osobowy radnego. Inne dane zamierzam wykorzystać w szerszym opracowaniu. Lista cech tworzących wzór osobowy polityka jest w analizowanych kodeksach bardzo rozbudowana. Powstała przez zestawienie propozycji obecnych w przywołanych wyżej kodeksach, poprzez próbę operacjonalizacji postulatów Legutki oraz rodzaj badania pilotażowego kodeksów, w wyniku którego lista cech uległa dalszemu poszerzeniu. Treść kodeksów była analizowana w oparciu o kwestionariusz, który - w części dotyczącej przedstawianego wzoru osobowego - ujawni się w dalszym ciągu. Przyjmuję potoczne rozumienie takiego wzoru, jako zespołu norm, cech, postaw charakteryzujących idealne cechy członka grupy radnych. Analizowane kodeksy były

16 R. Legutko, Etyka instytucji publicznych, dz. cyt., s. 13. 
przyjmowane przez rady różnych szczebli w latach 2005-2015. Najwięcej kodeksów przyjęto do 2010, a później pojedyncze.

Kodeksy etyczne radnych jednocześnie są stereotypowe i autentyczne. Są stereotypowe, ponieważ duża ich część powtarza propozycje obecne we wzorcowym kodeksie obecnym w Etycznych aspektach działalności samorządu terytorialnego. Poradnik dla samorządów. Z drugiej strony są autentyczne, ponieważ nie wszystkie zasady obecne we wzorcowym kodeksie są w nich obecne oraz wiele w nich powtórzeń, niekonsekwencji świadczących o tym, że tworzyło je wielu autorów niemających wcześniej styczności z tego typu dokumentami.

\section{Prezentacja wybranych wyników analizy kodeksów etycznych radnych}

Trudno w artykule przedstawić wszystkie interesujące problemy obecne w kodeksach etycznych radnych, nawet tylko wszystkie problemy dotyczące wzorów osobowych radnych. Pod uwagę biorę te kwestie, które określają stosunek radnych do:

1. zakresu stosowalności kodeksów,

2. zadań przypisywanych kodeksom,

3. państwa i politycznego otoczenia,

4. instytucji (rady), w której działa, norm, którymi kieruje się instytucja

5. wyborców (mieszkańców) oraz współpracowników (urzędników samorządowych).

Taki zestaw problemów wiąże się z próbą wykorzystania zasygnalizowanych wyżej sugestii Legutki. Zgodnie z nimi etyki polityków nie można sprowadzać do listy cnót. Równie ważne są różne konteksty, w których funkcjonują politycy. W artykule zajmuję się kontekstami, próbując zidentyfikować bardziej ukryte, dominujące składniki wzorów osobowych radnych. 


\section{Zakres stosowalności kodeksu}

W kodeksach etycznych radnych w odmienny sposób charakteryzuje się to, czy i w jakim stopniu zasady w nich obecne dotyczą tylko sytuacji, w których ktoś występuje jako radny, czy też dotyczą także pozostałych form aktywności, w szczególności zawodowej. W wielu kodeksach przedmiotem zainteresowania są również sytuacje związane $\mathrm{z}$ codziennym życiem, i to nie tylko w czasie bycia radnym, lecz także po zakończeniu pełnienia tej roli. Pierwsza sytuacja oznacza ograniczenie roli kodeksu do bycia radnym, pozostałe oznaczają rozszerzanie jego roli do całości życia.

Rozkład odpowiedzi przedstawia tab. 1.

Tab. 1. Zakres stosowalności kodeksu

\begin{tabular}{|l|l|l|}
\hline & Liczebność & \multicolumn{1}{c|}{ \% z N w wierszu } \\
\hline Rozszerzony (kodeks dotyczy całości życia) & 44 & 75,9 \\
\hline Ograniczony do bycia radnym & 9 & 15,5 \\
\hline Trudne do identyfikacji & 5 & 8,6 \\
\hline
\end{tabular}

Źródło: badania własne, $\mathrm{N}=58$

W kodeksach radnych zdecydowanie dominuje rozszerzone ${ }^{17}$ wyobrażenie roli radnego. Według tego ujęcia radnym jest się nie tylko w czasie sesji rady, zebrań komisji, w czasie kontaktów z mieszkańcami (wyborcami), lecz również w pracy, życiu codziennym i po zakończeniu kadencji. Z pewnością od każdego człowieka należy oczekiwać przestrzegania przyjętych zasad, jednak oczekiwanie od byłych radnych, że będą przestrzegać zasad specyficznych dla tej roli jest oczekiwaniem daleko idącym. Takie oczekiwanie warto zestawić z kolejnym

17 Niektóre kodeksy etyczne radnych tak daleko rozszerzają zakres ich stosowalności, że są bliskie temu, co pojawia się w części kodeksów etycznych firm i może być uznane za nadrzędzie tworzenia się „sekt korporacyjnych”. Zob. J. Szczupaczyński, Etyczne dylematy przywództwa, w: Przywództwo, etyka, polityka, red. nauk. E. M. Marciniak, J. Szczupaczyński, Warszawa 2018, s. 31-32. 
problemem obecnym w kodeksach - określeniem zadań samego kodeksu.

\section{Zadania kodeksu}

W kodeksach obecne są sformułowania definiujące ich zadania. W szczególności, gdy obserwuję rozkład odpowiedzi charakteryzujących zadania kodeksu, interesuje mnie, w jakim stopniu zadania są zgodne/ niezgodne z rozszerzoną rolą radnych. Biorąc poważnie wcześniejsze odpowiedzi dotyczące rozszerzonego rozumienia roli radnych, należałoby teraz oczekiwać dominacji odpowiedzi, że zadaniem kodeksu jest informowanie mieszkańców o obecnych w nim zasadach oraz że reguluje on stosunki między radnymi a wyborcami.

Rozkład odpowiedzi przedstawia tab. 2.

Tab. 2. Zadania kodeksu

\begin{tabular}{|l|l|l|}
\hline & Liczebność & \% z N w wierszu \\
\hline Kodeks określa standardy postępowania radnych & 44 & 76 \\
\hline $\begin{array}{l}\text { Zadaniem kodeksu jest informowanie mieszkańców o obec- } \\
\text { nych w nim zasadach }\end{array}$ & 18 & 31 \\
\hline Reguluje stosunki między radnymi a wyborcami & 8 & 14 \\
\hline
\end{tabular}

Źródło: badania własne, $\mathrm{N}=58$

Powyższe zestawienie sposobów charakteryzowania zadań kodeksów wskazuje na to, że ich przekaz jest kierowany przede wszystkim do samych radnych, choć obecność wyborców jest również znaczna, jednak niewspółmiernie mniejsza, niż należałoby oczekiwać z dominacji rozszerzonego sposobu pojmowania roli radnego.

\section{Stosunek do państwa i politycznego otoczenia}

Na cechy osobowe radnych składają się nie tylko ich cnoty, lecz także stosunek do otoczenia, w tym państwa i politycznego otoczenia (partii 
politycznych, komitetów wyborczych, klubów radnych). W kodeksach etycznych radnych można odczytać stosunek ich twórców do tych instytucji. Lista instytucji, wobec których radni określają swoje stanowisko, jest rozbudowana. Zwrócę uwagę na ich stosunek do: konstytucyjnej zasady podziału władz, istniejącego porządku prawnego, potrzeby uwzględniania różnych interesów.

Rozkład odpowiedzi przedstawia tab. 3 .

Tab. 3. Stosunek do państwa i politycznego otoczenia

\begin{tabular}{|l|l|l|}
\hline & Liczebność & \% z N w wierszu \\
\hline Przestrzeganie istniejącego porządku prawnego & 42 & 72 \\
\hline $\begin{array}{l}\text { Obecna jest akceptacja konstytucyjnej zasady podzia- } \\
\text { łu władz }\end{array}$ & 30 & 52 \\
\hline $\begin{array}{l}\text { Obecny jest nakaz uwzględniania różnych interesów (pań- } \\
\text { stwa, wspóllnoty samorządowej, indywidualnego interesu } \\
\text { mieszkańców) }\end{array}$ & 22 & 38 \\
\hline Obecna jest akceptacja demokracji & 3 & 5 \\
\hline $\begin{array}{l}\text { Obecne są reguły określające relacje z instytucjami poli- } \\
\text { tycznymi desygnującymi radnych (partie, komitety wy- } \\
\text { borcze) }\end{array}$ & 3 & 5 \\
\hline Obecne są zasady prowadzenia kampanii wyborczych & 1 & 2 \\
\hline Obecne są kluby radnych & 1 & 2 \\
\hline
\end{tabular}

Źródło: badanie własne, $\mathrm{N}=58$

W większości kodeksów, choć nie we wszystkich, można zauważyć akceptację istniejącego porządku prawnego oraz konstytucyjnej zasady podziału władz. W dużej części kodeksów (lecz nawet nie w 50\%) zawarto nakaz uwzględniania przez radnych różnych interesów. Natomiast tylko w kilku dokumentach obecna jest akceptacja demokracji. Trudno powiedzieć, dlaczego w tak nikłym stopniu obecna jest akceptacja demokracji. Czy demokracja traktowana jest jako oczywistość niewymagająca wzmianki, czy też stosunek do demokratycznego państwa został określony w aprobacie do konstytucyjnej zasady podziału władz? Zresztą wcale nie tak powszechnej. Czy wynika ze skupienia się na tym, co lokalne, 
bez potrzeby odwołania się do kwestii wykraczających poza lokalność? Sformułowania dotyczące demokracji nie są rozbudowane, przyjmują postać podobnych wzmianek wiążących etykę z demokracją. Według tego ujęcia etyka odgrywa szczególną rolę $\mathrm{w}$ funkcjonowaniu demokracji. Tylko w pojedynczych kodeksach obecne są zasady prowadzenia kampanii wyborczych (dość szczegółowe) oraz zauważa się istnienie klubów radnych i w konsekwencji konieczność określenia stosunku radnych do tej, powszechnie występującej, instytucji politycznej. Ten fakt nikłej obecności w kodeksach instytucji politycznych, powszechnych w otoczeniu radnych, ich ignorowanie wyraźnie świadczy o braku realizmu. Przecież wiele zachowań polityków, także radnych, nie jest efektem posiadanych przez nich cnót, lecz rozstrzygnięć zapadających w organizacjach politycznych, do których należą i które wymagają od nich lojalności.

\section{Stosunek do wspólnoty samorządowej oraz rady, w której działa radny}

Stosunek do wspólnoty samorządowej oraz rady, w której radny działa, jest pytaniem o stopień (także granice) lojalności radnych wobec instytucji, w których działają i na które mają znaczący wpływ. W szczególności jest to pytanie o lojalność wobec wartości przypisywanych wspólnocie i radzie.

Rozkład odpowiedzi przedstawia tab. 4 .

Tab. 4. Stosunek do wspólnoty samorządowej oraz rady, w której działa radny

\begin{tabular}{|l|l|l|}
\hline & Liczebność & \% z N w wierszu \\
\hline Kodeks nakazuje dbałość o interes publiczny & 42 & 72 \\
\hline Obecny jest nakaz troski o dobre imię rady & 35 & 60 \\
\hline $\begin{array}{l}\text { Kodeks przewiduje pierwszeństwo interesu publicznego nad } \\
\text { osobistym }\end{array}$ & 32 & 55 \\
\hline $\begin{array}{l}\text { Obecny jest nakaz przestrzegania kompetencji organów gmi- } \\
\text { ny, miasta, powiatu }\end{array}$ & 27 & 47 \\
\hline
\end{tabular}


Dane znajdujące się w tab. 4 wskazują na stosunkowo wysoki (jednak nie powszechny) stopień zauważania problemu lojalności radnych wobec instytucji, których są członkami. Są również w dużym stopniu wobec nich lojalni. W zdecydowanej większości kodeksów (lecz nie wszystkich) obecny jest nakaz dbałości o interes publiczny. W większości zawarto nakaz troski o dobre imię rady. W jeszcze mniejszym stopniu, choć ciągle w większości, obecny jest nakaz pierwszeństwa interesu publicznego nad osobistym. W mniejszej części kodeksów sformułowano nakaz przestrzegania kompetencji organów gminy, miasta, powiatu. Aprobata dla tej zasady jest zrozumiała. Jednocześnie warto zwrócić uwagę na tę deklarację, ponieważ w kodeksach obecne są również deklaracje o aprobowaniu konstytucyjnej zasady podziału władz (tab. 3, aprobata taka występuje w 52\% kodeksów). Takie powtórzenie świadczy zapewne o wadze tego problemu dla radnych. Może też świadczyć o zdominowaniu radnych przez organy wykonawcze, na co wskazywałyby raporty analizujące funkcjonowanie samorządów. Według jednego $\mathrm{z}$ nich ${ }^{18} \mathrm{w}$ samorządach terytorialnych dostrzegalne są liczne dysfunkcje, w tym autorytaryzm. Polega on na zdominowaniu radnych przez instytucje wykonawcze.

\section{Stosunek do wyborców oraz współpracowników (pracowników samorządowych)}

Pytanie o stosunek radnych do wyborów (mieszkańców) oraz współpracowników jest jednym $\mathrm{z}$ najważniejszych, ponieważ tutaj ujawnia się nie tylko deklarowane, lecz faktyczne nastawienie - z jednej strony - do demokratycznego systemu oraz do osób, dzięki którym zostali radnymi, a z drugiej - do tego, jak traktują współpracowników, dzięki którym mogą funkcjonować jako radni. Ujawnia się również ich stanowisko wobec zauważanego przez badaczy dylematu, czy samorząd terytorialny ma być obywatelski czy menedżerski ${ }^{19}$.

18 Zob. Narastające dysfunkcje, zasadnicze dylematy, konieczne działania. Raport o stanie samorząności terytorialnej w Polsce, Kraków 2013, s. 81n.

19 Zob. Narastające dysfunkcje, zasadnicze dylematy, konieczne działania..., dz. cyt., s. 92. 
Rozkład odpowiedzi przedstawia tab. 5 .

Tab. 5. Stosunek do wyborców, do współpracowników

\begin{tabular}{|l|l|l|}
\hline & Liczebność & \% z N w wierszu \\
\hline $\begin{array}{l}\text { Obecny jest nakaz kontaktu z wyborcami: spotkania, przyj- } \\
\text { mowanie skarg }\end{array}$ & 38 & 66 \\
\hline Obecne są zasady kontaktu z mediami & 22 & 38 \\
\hline Obecny jest nakaz uwzględniania oczekiwań mieszkańców & 11 & 18 \\
\hline Obecny jest tylko nakaz informowania wyborców & 11 & 18 \\
\hline Obecne są zasady kontaktu z pracownikami samorządowymi & 5 & 8 \\
\hline Obecny jest nakaz szacunku dla pracowników samorządowych & 4 & 7 \\
\hline $\begin{array}{l}\text { Obecny jest nakaz uznawania uprawnień i prerogatyw pra- } \\
\text { cowników samorządowych }\end{array}$ & 3 & 5 \\
\hline
\end{tabular}

Źródło: badania własne, $\mathrm{N}=58$

W kodeksach zawarto wiele szlachetnie brzmiących wypowiedzi, norm określających właściwy sposób odnoszenia się do wyborców. W większości obecny jest nakaz kontaktowania się z wyborcami. Jednak są to puste deklaracje, ponieważ najważniejsza norma, że radni powinni uwzględniać oczekiwania wyborców, występuje tylko w 18\% kodeksów. Natomiast dominują - skądinąd ważne - normy dotyczące godnego zachowania, informowania, spotykania się. Nie zastąpią one jednak przekonania, że w swoich działaniach radni powinni uwzględniać oczekiwania wyborców. Tylko takie podejście oznacza podmiotowe traktowanie wyborców. Natomiast nakazy spotykania się, informowania wskazują na paternalistyczne traktowanie mieszkańców. Nawet nakaz kontaktowania się z mediami, jednym z najważniejszych narzędzi informowania opinii publicznej, występuje tylko w 38\% kodeksów. Jak piszą autorzy przywoływanego Raportu: „Obywatel jest w systemie samorządowym traktowany przedmiotowo - ma co cztery lata iść na wybory i głosować, zaś samorząd (administracja) jest traktowany podmiotowo - samorząd to właśnie ci, którzy na 4 lata są wybrani i mogą robić co chcą"20.

20 Narastające dysfunkcje, zasadnicze dylematy, konieczne działania..., dz. cyt., s. 92. 
Jeszcze w mniejszym stopniu kodeksy etyczne radnych zauważają swoich współpracowników, urzędników samorządowych. Tylko w pięciu kodeksach obecne są zasady kontaktów z pracownikami, w czterech nakaz szacunku, a nakaz uznawania ich uprawnień tylko w trzech. Warto tę informację zestawić $\mathrm{z}$ danymi $\mathrm{z}$ tab. 4, skąd dowiadujemy się, że w niemal połowie kodeksów ( $47 \%$ ) obecny jest nakaz przestrzegania kompetencji organów gminy, miasta, powiatu, tzn. wójta, burmistrza, starosty, prezydenta miasta. Zauważane są więc kompetencje organów wykonawczych, a nie są zauważane uprawnienia pracowników samorządowych. Aby zasygnalizować, o co chodzi, warto zacytować jeden z kodeksów, w którym ten problem jest wyróżniony: „Radni przy wykonywaniu swoich funkcji powinni uznawać uprawnienia i prerogatywy wszystkich innych radnych i wszystkich urzędników publicznych"21.

\section{Uwagi końcowe}

W kodeksach etycznych radnych, w wątkach budujących wzór osobowy polityka, występuje wiele interesujących problemów, zwrócę uwagę na kilka.

Kodeksy etyczne radnych konstruują rozszerzony wzorzec radnego, ponieważ w zdecydowanej większości oczekują, że zasady w nich zawarte powinny obejmować nie tylko te działania radnych, które bezpośrednio wiążą się $\mathrm{z}$ ich aktywnością polityczną, aktywnością $\mathrm{w}$ radzie, lecz także to, co czynią w życiu zawodowym, nawet po zakończeniu działalności w radzie. Kodeksy, co jest zrozumiałe, akceptują porządek prawny. Jednak wyjątkowo rzadko pojawia się akceptacja demokracji. Tylko w 18\% kodeksów obecne są nakazy uwzględniania oczekiwań wyborców, a w 14\% przyjmuje się, że kodeks reguluje stosunki między radnymi a wyborcami. Te i niewzięte tutaj pod uwagę deklaracje pozwalają stwierdzić, że kodeksy są paternalistyczne. Nie traktują wyborców (także pracowników samorządowych) podmiotowo, obywatelsko. Charakteryzuje je tylko postawa życzliwości, bez zwracania uwagi na to, że wyborcy mają prawo domagać się realizacji swoich oczekiwań. Odwołując się

${ }^{21}$ Kodeks etyczny radnego w Grudziądzu. 
do przywoływanego wcześniej Raportu², można powiedzieć, że w kodeksach etycznych radnych dominuje menedżerski, a nie obywatelski model samorządności. W jednym $\mathrm{z}$ kodeksó $\mathrm{w}^{23}$ dystans wobec innych jest tak daleko posunięty, że relacje między radnymi i pracownikami samorządowymi ujmuje się w kategoriach hierarchiczności.

Kodeksy etyczne radnych nie są również realistyczne. Nie zauważają instytucjonalnych, politycznych uwarunkowań swoich działań i przez to nie proponują sposobów rozstrzygnięć ewentualnych konfliktów (także etycznych) między radnymi a tymi instytucjami. Udają, że kluby radnych, partie polityczne, komitety wyborcze nie decydują (współdecydują) o ich zachowaniach.

Na koniec warto odpowiedzieć, czy i w jakim stopniu kodeksy etyczne radnych realizują oczekiwania sformułowane wobec etyki polityki przez Legutkę ${ }^{24}$. Przypomnę, że ten filozof i polityk po zreferowaniu dyskusji dotyczącej relacji między etyką osobową a „etyką" instytucji proponuje trzy poziomy odpowiedzialności polityków konstruujące etykę polityki/polityków. Są to: odpowiedzialność wobec instytucji, wyborców, własnego sumienia. Odpowiedzi zawarte w przeanalizowanych kodeksach etycznych radnych nie są w tych kwestiach jednoznaczne. Jeśli idzie o odpowiedzialność wobec współtworzonych instytucji (rada, klub radnych, komitet wyborczy), to $z$ jednej strony w $60 \%$ kodeksów obecny jest nakaz troski o dobre imię rady, w $47 \%$ nakaz przestrzegania kompetencji organów gminy, miasta powiatu. Z drugiej strony, tylko w pojedynczych kodeksach obecne są zasady określające relacje między radnymi a ich komitetami wyborczymi, klubami radnych, choć są to instytucje powszechnie obecne w działalności radnych i znacząco wpływające na ich działalność. Podobna niejednoznaczność występuje w określeniu odpowiedzialności radnych wobec mieszkańców. Wprawdzie w $66 \%$ kodeksów zawarty jest nakaz kontaktowania się z mieszkańcami (to znaczy także, że takiego nakazu nie ma w 1/3 kodeksów), lecz tylko

\footnotetext{
22 Narastające dysfunkcje, zasadnicze dylematy, konieczne działania..., dz. cyt., s. 92.

${ }_{23}$ Zob. Kodeks etyczny radnego w Grudziądzu.

${ }^{24}$ Zob. R. Legutko, Etyka instytucji publicznych, dz. cyt., s. 11-17.
} 
w 18\% obecny jest nakaz uwzględniania oczekiwań wyborców. Jeśli idzie o odpowiedzialność radnych wobec własnego sumienia, to trzeba stwierdzić, że w kodeksach etycznych pojęcie to nie występuje. Najbliżej tego pojęcia sytuują się zadania stawiane przez radnych kodeksom. W $76 \%$ kodeksów obecne są stwierdzenia, że kodeks określa standardy postępowania radnych, a w $31 \%$, że zadaniem kodeksu jest informowanie mieszkańców o obecnych w nim zasadach (w kodeksach jednocześnie bywają jedne i drugie zadania). Można więc powiedzieć, że radni skupieni są na sobie samych. Tylko w 14\% kodeksów stwierdzają oni, że dokumenty te regulują stosunki między nimi a wyborcami.

Można więc powiedzieć, że kodeksy etyczne radnych w ograniczonym stopniu zauważają zasygnalizowane wcześniej dylematy etyczne obecne w ich działalności i dają niejednoznaczne odpowiedzi. Dlatego w ograniczonym stopniu mogą przeciwdziałać istniejącym nieetycznym zachowaniom występującym w ich działalności.

\section{Lista wykorzystanych kodeksów etycznych radnych}

Kodeks etyczno-moralny radnego Miasta i Gminy Lądek-Zdrój

Kodeks etyczny radnego Gminy Brwinów

Kodeks etyczny radnego Gminy i Miasta Dobczyce

Kodeks etyczny radnego Gminy Kętrzyn

Kodeks etyczny radnego Gminy Kobylanka

Kodeks etyczny radnego Powiatu Grodziskiego

Kodeks etyczny radnego Rady Miasta w Piotrkowie Trybunalskim

Kodeks etyczny radnego Rady Miejskiej w Bukownie

Kodeks etyczny radnego Rady Miejskiej w Jarocinie

Kodeks etyczny radnego Rady Miejskiej w Lublińcu

Kodeks etyczny radnego w Grudziądzu

Kodeks etyczny radny Rady Powiatu Drawskiego

Kodeks etyczny radnych Miasta Milanówek

Kodeks etyczny radnych Powiatu w Gołdapi

Kodeks etyczny radnych Rady Gminy Bukowiec

Kodeks etyczny radnych Rady Gminy Chełmiec 
Kodeks etyczny radnych Rady Gminy Gołcza

Kodeks etyczny radnych Rady Gminy Kwilicz

Kodeks etyczny radnych Rady Gminy Sadki

Kodeks etyczny radnych Rady Gminy Sierpc

Kodeks etyczny radnych Rady Gminy Ustka

Kodeks etyczny radnych Rady Gminy w Chodzieży

Kodeks etyczny radnych Rady Miasta Czarnków

Kodeks etyczny radnych Rady Miasta Torunia

Kodeks etyczny radnych Rady Miasta Wąbrzeźno

Kodeks etyczny radnych Rady Miejskiej Legnicy

Kodeks etyczny radnych Rady Miejskiej w Czechowicach-Dziedzicach

Kodeks etyczny radnych Rady Miejskiej w Kluczborku

Kodeks etyczny radnych Rady Miejskiej w Koronowie

Kodeks etyczny radnych Rady Miejskiej w Mielcu

Kodeks etyczny radnych Rady Miejskiej w Nowym Tomyślu

Kodeks etyczny radnych Rady Miejskiej w Ożarowie Mazowieckim

Kodeks etyczny radnych Rady Miejskiej w Strzegomiu

Kodeks etyczny radnych Rady Miejskiej w Trzebiatowie

Kodeks etyczny radnych Rady Miejskiej w Glinojecku

Kodeks etyczny radnych Rady Pieniężno

Kodeks etyczny radnych Rady Powiatu w Bielsku Podlaskim

Kodeks etyczny radnych Radym Miejskiej w Łobzie

Kodeks etyki radnego i członka zarządu Powiatu Kwidzyn

Kodeks etyki radnego Miasta Płocka

Kodeks etyki radnego Powiatu Jaworskiego

Kodeks etyki radnego Powiatu Poznańskiego

Kodeks etyki radnego Powiatu Radomskiego

Kodeks etyki radnego Powiatu Zielonogórskiego

Kodeks etyki radnego Rady Gminy w Łagowie

Kodeks etyki radnego Rady Miejskiej w Brzesku

Kodeks etyki radnego samorządu Powiatu Średzkiego

Kodeks etyki radnych Gminy Raciechowice

Kodeks etyki radnych miasta Częstochowy

Kodeks etyki radnych Miasta Zgierza 
Kodeks etyki radnych Powiatu Kluczborskiego

Kodeks etyki radnych Powiatu Przasnyskiego

Kodeks etyki radnych Powiatu Tarnogórskiego

Kodeks etyki radnych Rady Gminy Banie

Kodeks etyki radnych Rady Miejskiej w Kożuchowie

Kodeks etyki radnych Rady Miejskiej w Nowogrodzie Bobrzańskim

Kodeks etyki radnych Rady Powiatu Kędzierzyńsko-Kozielskiego

Zasady etyki radnego Miasta Szczecina

\section{Bibliografia}

Etyczne aspekty działalności samorządu terytorialnego. Poradnik dla samorządów, pod red. J. Filek, Kraków 2004.

Kodeks etyczny radnego w Grudziądzu, http://bip.grudziadz.pl/strony/2128.dhtml (23.01.2018).

Kodeks etyki radnych samorządu terytorialnego - projekt, w: Etyczne aspekty działalności samorządu terytorialnego. Poradnik dla samorządów, pod red. J. Filek, Kraków 2004, s. 238-241.

Honorowy kodeks radnego, w: Standardy etyczne radnych i pracowników samorządowych, red. M. Korkuć, P. Stańczyk, Kraków 2000 s. 75-77.

Konstańczak S., Odkryć sens życia w swej pracy, Słupsk 2000.

Kowalczyk S., Człowiek a społeczność. Zarys filozofi społecznej, Lublin 1994.

Krapiec M. A., O ludzka politykę, Katowice 1993.

Krąpiec M. A., Ludzka wolność i jej granice, Warszawa 1997.

Legutko R., Etyka instytucji publicznych, w: Standardy etyczne radnych i pracowników samorządowych, red. M. Korkuć, P. Stańczyk, Kraków 2000, s. 11-17.

Majcherek J. A., Demokracja, przygodność, relatywizm, Warszawa 2007.

Majcherek J. A., Hipertrofia moralności jako zagrożenie dla demokracji, w: Wartości w świecie polityki, red. nauk. J. Miluska, Poznań 2012, s. 113-122.

Modzelewski E., Etyka a polityka, Warszawa 2006.

Narastające dysfunkcje, zasadnicze dylematy, konieczne działania. Raport o stanie samorządności terytorialnej w Polsce, Kraków 2013.

Szczupaczyński J., Etyczne dylematy przywództwa, w: Przywództwo, etyka, polityka, red. nauk. E. M. Marciniak, J. Szczupaczyński, Warszawa 2018, s. 30-48. 
Szyszkowska M., Wprowadzenie, w: Polityka a moralność, pod red. M. Szyszkowskiej,

T. Kozłowskiego, Warszawa 2001, s. 9-10.

Uchwała Sejmu Rzeczpospolitej Polskiej z dnia 17 lipca 1998 r. Zasady etyki poselskiej, http://www.sejm.gov.pl/prawo/zep.htm.

Zell Z., Kodeks poselski, „Wspólnota. Pismo Samorządu Terytorialnego” 1998 nr 33, s. 6.

\section{Abstrakt}

\section{Wzory osobowe polityka w kodeksach etycznych radnych}

Kodeksy etyczne, także kodeksy etyczne polityków, przyjmowane są po to, aby przeciwdziałać różnym nieetycznym zachowaniom. W artykule, na podstawie analizy 58 kodeksów etycznych radnych, przedstawione są wybrane elementy i dylematy wzorów osobowych polityków. Autor pyta, czy kodeksy etyczne radnych mogą przeciwdziałać nieetycznym zachowaniom. Odpowiada, że część z nich nie może im przeciwdziałać, ponieważ nie spełnia formułowanych wobec nich oczekiwań.

\section{Słowa kluczowe}

etyka, etyka polityki, filozofia polityki, kodeksy etyczne, kodeksy etyczne polityków

\section{Abstract}

\section{Personal patterns in ethical codes of councilors}

Ethical codes, including ethical codes of politicians, are adopted to counteract various unethical behaviors. In the article, based on the analysis of 58 ethical codes of councilors, selected elements and dilemmas of personal patterns of politicians (councilors) were presented. The author asks whether ethical codes of councilors can counteract such negative behaviors? He answers that some of them cannot counteract unethical behavior, because they do not meet the expectations formulated for them.

\section{Keywords}

ethics, ethics of politics, philosophy of politics, ethical codes, ethical codes of politicians 